\title{
The effect of public employment on children's work and school attendance: evidence from a social protection program in Argentina
}

Randall Juras

Correspondence:

randall_juras@abtassoc.com

Abt Associates Inc, 55 Wheeler St, Cambridge, MA 02138, USA

\begin{abstract}
I assess the short-term impact of a public employment program on child labor and school attendance in Argentina. Public employment increases opportunities for adults outside the household, and may correspondingly raise the returns to children's productive activities at home. The effect of public employment on school attendance may thus be small. However, I find that the program substantially increased children's school attendance in addition to reducing child labor. My empirical strategy exploits an arbitrary enrollment cutoff date to compare program beneficiaries with a propensity-matched group of applicants not receiving benefits.
\end{abstract}

Keywords: Child labor; Public employment; Social protection; Argentina

JEL classification: J22; J13; J68; 015

\section{Introduction}

The severe economic crisis that hit Argentina at the end of 2001 resulted in a doubling of poverty and extreme poverty. In response, the government implemented a public employment scheme called Jefes y Jefas de Hogar Desocupados (Jefas). The main purpose of Jefas was to alleviate suffering by providing cash to poor families with children. By bolstering household income, program designers hoped to improve children's well-being.

The existence of a relationship between household income and children's work and school attendance has been well-established, both theoretically (Basu and Van 1998) and empirically (e.g. Fiszbein and Schady 2009). Indeed, a large literature demonstrates that pure and conditional cash transfer programs (CCTs) reduce child labor and increase school attendance (Schultz 2004; Attanasio et al. 2006; Filmer and Schady 2008; Edmonds and Schady 2009).

However, a key difference between public employment and cash transfers is that by requiring parents to increase their work hours outside of the home, public employment may raise the returns to children's productive activities in the household and thus increase the opportunity cost of school attendance. The Jefas program required participants to work 20 hours per week in order to receive benefits. In contrast, CCTs have been shown to modestly reduce participants' hours of paid work (Fernandez and Saldarriaga 2014). As a result, the impact on children's school attendance may be smaller for public employment than for CCTs.

(C) 2014 Juras; licensee Springer. This is an Open Access article distributed under the terms of the Creative Commons Attribution License (http://creativecommons.org/licenses/by/4.0), which permits unrestricted use, distribution, and reproduction in any medium, provided the original work is properly credited. 
In this paper, I estimate the impact of Jefas on child work and school attendance for children ages 10-14 by comparing Jefas participants with a propensity-matched group of program applicants who were not receiving benefits. The same basic strategy was used by Galasso and Ravallion (2004) to estimate the effect of Jefas participation on adult employment, incomes, and poverty as well as to study program targeting and distributional impacts.

Galasso and Ravallion (2004) found that Jefas had only a small effect on the overall poverty rate but a larger effect on the extreme poverty rate. They also found that the program's work requirement was largely binding and that targeting was good, with about half of Jefas participants coming from the poorest fifth of Argentine families. However, a large share of program participants were women who would not otherwise have been in the labor force. For that reason, the program was only able to reduce the unemployment rate by $2.5 \%$, rather than the $5 \%$ reduction that would have occurred had all participants been otherwise unemployed.

Building on Galasso and Ravallion's (2004) empirical strategy, I find that the Jefas program was beneficial for children's work and school attendance. Using crosssectional data, I find that children age 10-14 whose parents enrolled in the Jefas program and received benefits were $46 \%$ (0.6 percentage points) less likely to report working and $38 \%$ (2.0 percentage points) less likely to forgo schooling, compared with similar children whose parents had applied but were not enrolled. Matched differencein-differences estimates using a smaller panel sample confirm these results, suggesting program effects of 0.8 percentage points on child work and 1.8 percentage points on school attendance. These findings demonstrate that public employment can be effective at both reducing child work and increasing school attendance.

The remainder of this paper is structured as follows. I describe the background and institutional details of the Jefas program in section 2. In Section 3 I describe the data, and in Section 4 I present descriptive statistics of the sample used for analysis. I outline the empirical methodology in Section 5, and present the main results in Section 6. Additional analyses and sensitivity checks are presented in Section 7. Section 8 concludes.

\section{Background on the economic crisis and the Jefas program}

A severe economic crisis hit Argentina at the end of 2001, brought about by default on external debt and a sharp devaluation in the Argentine peso. As a result, many workers saw substantial declines in their real incomes and the country overall experienced a doubling of poverty and extreme poverty. Households without savings had difficulty adjusting to the downturn, as most affected workers were unable to mitigate the effect of the crisis by increasing their work hours (McKenzie 2004).

Anecdotal evidence suggests that some families attempted to cope with the crisis by sending individuals other than the primary worker-including children-into the workforce to compensate for the decline in real wage income. Indeed, while estimates of child work in Argentina vary considerably, news sources at the time of the crisis reported an increase in child work (Palacios 2003) and corresponding decline in school attendance (Hennigan 2003). Likewise, according to the Bureau of International Affairs (2009), UNICEF reported a 600\% increase in child work between 1995 and 2003, with 40\% of those children who worked abandoning school, and ILO-IPEC (2002) reported an increase in child work between 1997 and 2002 which it attributed to the economic crisis. 
The government's primary safety-net response to the crisis was a large World Bank financed public employment program called Programa Jefes y Jefas de Hogar Desocupados ("Unemployed Male and Female Heads of Household Program"), or Jefas. The main purpose of Jefas was to alleviate suffering by providing cash to poor families with children. A secondary purpose was to lower the official unemployment rate by providing work opportunities to the unemployed.

Public employment schemes are an increasingly popular method of transferring income to poor households in developing countries. Safety-net programs of this type can be relatively easy to roll out and, if well designed, allow beneficiaries to self-select into the program (Ravallion 1990; Besley and Coate 1992). Participants in Jefas were required to engage in an eligible work or job-training activity no less than 4 hours per day, 5 days per week.

The total number of work opportunities was initially limited, so participants were enrolled into the program on a first-come, first-serve basis as opportunities became available. Participants received a monthly wage of AR $\$ 150$ (about US\$50). This amount was set to be below the expected full-time wage rate for households in the bottom decile of the earnings distribution so as not to attract individuals who were already employed ${ }^{1}$.

Program eligibility was limited to one adult per household. Because the program was intended for parents, applicants also had to prove that children under the age of 18 or a disabled adult were present in the household. These requirements were strictly enforced. Several additional formal eligibility requirements for individual applicants, including unemployment and status as the head of household, were not enforced (Galasso and Ravallion, 2004).

Jefas began accepting applications in Spring 2002 and the program experienced rapid growth, increasing in size from 574,000 participants in May 2002 to 1,857,000 in December 2002, with aid reaching an estimated 10 million family members in participating households. The ultimate size of the applicant pool exceeded what both the World Bank and the government had expected based on estimates of the target population (World Bank 2006). This resulted in serious budgetary pressures even though most other safety net programs were eliminated or reduced in order to shift funding to Jefas. As a result, registration was abruptly closed in September 2002 with only $65 \%$ of applicants having been enrolled (i.e. assigned to participate in work opportunities). Applicants were not given prior notice of the September 2002 deadline and most applicants remaining on the waiting list at that time were subsequently unable to enroll in the program ${ }^{2}$.

\section{Data}

This analysis uses data from the October 2001 and October 2002 rounds of the Encuesta Permanente de Hogares (EPH). The EPH survey is administered twice per year, in May and October, by the National Institute for Census and Statistics (INDEC). The EPH provides a representative sample in 31 large urban areas that together represent approximately $70 \%$ of Argentina's urban population and $60 \%$ of its total population.

The EPH was modeled after-and as a result is similar to-the Current Population Survey in the United States. The sample consists of residences (households) for which interviews are conducted in-person. Data are recorded separately for each occupant (including children). Because the primary purpose of the EPH is the systematic 
collection of workforce data, survey staff attempt to accommodate the work schedules of respondents when scheduling interviews. Interviewers have a one-week window during which to conduct interviews for any given residence. Responses are kept strictly anonymous.

The EPH includes a short-duration longitudinal component. Each household is contacted during four consecutive survey waves, with one-quarter of households rotated out of the sample in each wave and replaced with newly-selected households. Approximately one-half of residences can thus be linked as a panel between the October 2001 and October 2002 survey waves.

The October 2002 survey round was conducted after enrollment in Jefas had ended. I use data from Oct. 2002 to select the primary analysis sample and to measure postprogram outcomes. The Oct. 2001 survey round was completed prior to the onset of the economic and political crisis in November-December 2001 and well prior to the subsequent initiation of the Jefas program in Spring 2002. I therefore use the Oct. 2001 survey round to measure pre-intervention baseline characteristics for the sample of households interviewed in both survey waves.

In this study I estimate impacts by comparing the outcomes for children in participant households (i.e. households that had enrolled in the Jefas program and were receiving benefits in Oct. 2002) with the outcomes of children in a propensity-matched group of applicant households (i.e. households that had applied to the program but were still on the waiting list at the time of the October 2002 survey). This strategy was previously used by Galasso and Ravallion (2004) to estimate the impact of the Jefas program on adult labor market outcomes. As they argue, applicants' demonstrated preference for program participation makes them an appealing comparison group. Furthermore, the rapid scale-up of the program and large size of the waiting list imply that selection of participants may have been somewhat random. I will return to a discussion of the estimation strategy in Section 5.

Jefas participants and applicants are identified in the EPH using the October 2002 survey, which included a special module on Jefas participation. This module was designed for program evaluation and was administered to both participants and applicants not yet receiving benefits ${ }^{3}$. The 2002 survey data used in this paper include observations on 1,136 households with a Jefas participant and 399 households with a Jefas applicant. Galasso and Ravallion (2004) found that the EPH slightly under-reports participation in Jefas, but concluded that the discrepancy "is not large enough to warrant serious concern about sampling bias in the EPH".

I construct a panel sample of participants and applicants by merging the Oct. 2002 and Oct. $2001 \mathrm{EPH}$ samples. Because the EPH is a sample of residences and not individuals, it is likely that some residences have different occupants across the two years. To ensure the highest proportion of "valid" merges between 2001 and 2002 (i.e. households with the same occupants in both years), I follow the recommendation of Madrian and Lefgren (2000) for CPS data and exclude certain suspect observations. Specifically, I exclude individuals whose gender differs between 2001 and 2002 or whose age changes by less than -1 or more than 3 years ${ }^{4}$. All told, $4.9 \%$ of the participant sample and $3.6 \%$ of the applicant sample were excluded for this reason. This process creates the possibility of bias due to sample attrition, which is a limitation of the longitudinal analysis. However, any such bias is likely to be small due to the small number of 
exclusions. The final panel dataset includes observations on 504 households with a participant and 164 households with an applicant.

Work and school attendance outcomes are measured using the Oct. 2002 survey. I assess these outcomes for children ages 10-14 only. This age range was chosen to be representative of children who are on the margin of work and school attendance; i.e. most vulnerable to pressures to skip school and/or begin working in dire economic circumstances despite formal prohibitions. This decision was driven by institutional knowledge and empirical evidence.

Work for pay appears to be very rare for children under the age of 10 in Argentina, perhaps due to stigma. In the data used for this analysis, the reported prevalence of work is approximately zero for children under age 10. In contrast, work for pay is legal under some circumstances for children older than 14, who are allowed by law to work up to 6 hours per day if granted special permission from administrative authorities (Bureau of International Affairs 2009).

Argentina's public education system is free and compulsory for children between the ages of 5 and 15 (Bureau of International Affairs 2009). In the EPH data, the reported rate of school attendance is greater than $98 \%$ for children under the age of 10 but begins to fall after that age. According to Argentina's Census and Statistics Institute (INDEC, 2001), more than $79 \%$ of children who enrolled in primary school in Argentina complete primary education through grade 9 (usually age 14).

For children ages 10-14, I code "works" as a binary variable equal to 1 if the child is reported as working for pay at any point during the survey reference week, and I code "attends school" as a binary variable equal to 1 if the child is reported as attending school during the reference week. Analyses in this paper are generally performed at the household level, with child-level outcomes aggregated within households as "percent of children working" and "percent of children attending school".

\section{Sample descriptive statistics}

Table 1 presents baseline (pre-program) descriptive statistics, including the outcomes of interest, for the sample of 668 households (984 children) in the 2001-2002 panel dataset. Table 1 presents estimates separately by the household's application status. In all descriptive tables, household-level observations are weighted by number of children. Therefore, the reported estimates represent child-level means with standard errors clustered by household.

The observable attributes presented in Table 1 are well-balanced between participants and applicants. Table 1 suggests statistically significant evidence of baseline imbalance for only 1 out of the 11 observable baseline characteristics (and neither of the outcomes of interest) at $\mathrm{p}<0.10^{5}$. However, the one characteristic that exhibits a statistically significant difference, rooms per person, is a particularly problematic one. This characteristic is sometimes used as a proxy for household wealth, and the difference is in the direction that would be expected if the neediest households were first to apply (i.e. participants, who applied first, are less wealthy than applicants). Therefore, the possibility the participants and applicants differ on important unobservable characteristics should not be ruled out.

With respect to published estimates of child work in Argentina's urban areas, it also appears that child work may be slightly underreported in the EPH. For example, in 
Table 1 Baseline (2001) descriptive statistics for panel dataset

\begin{tabular}{lcccccc}
\hline & \multicolumn{2}{c}{ Participants } & \multicolumn{2}{c}{ Applicants } & \multicolumn{2}{c}{$\begin{array}{c}\text { Difference } \\
\text { (part. - appl.) }\end{array}$} \\
& Mean & St.err. & Mean & St.err. & Value & T-stat \\
\hline $\begin{array}{l}\text { Outcomes of interest (2001) } \\
\text { Child works }\end{array}$ & 0.011 & $(0.004)$ & 0.008 & $(0.007)$ & $-\mathbf{0 . 0 0 2}$ & [0.29] \\
Child attends school & 0.985 & $(0.005)$ & 0.983 & $(0.010)$ & $\mathbf{0 . 0 0 2}$ & {$[0.20]$} \\
Attributes of children (2001) & & & & & & \\
Male & 0.514 & $(0.018)$ & 0.500 & $(0.034)$ & 0.016 & {$[0.43]$} \\
Age & 10.86 & $(0.490)$ & 10.90 & $(0.840)$ & -0.034 & {$[0.34]$} \\
Attributes of the household (2001) & & & & & & \\
Located in a shantytown & 0.051 & $(0.010)$ & 0.063 & $(0.019)$ & -0.012 & {$[0.58]$} \\
Bathroom & 0.885 & $(0.014)$ & 0.908 & $(0.023)$ & -0.023 & {$[0.83]$} \\
Rooms per person & 0.435 & $(0.012)$ & 0.501 & $(0.022)$ & -0.066 & {$[2.77]^{* * *}$} \\
Number of children <18 in hhld & 4.212 & $(0.098)$ & 4.000 & $(0.181)$ & 0.216 & {$[1.07]$} \\
Single household head & 0.082 & $(0.017)$ & 0.079 & $(0.029)$ & 0.003 & {$[0.05]$} \\
Married household head & 0.447 & $(0.014)$ & 0.487 & $(0.025)$ & -0.040 & {$[1.37]$} \\
Household size & 7.093 & $(0.134)$ & 6.766 & $(0.206)$ & 0.327 & {$[1.24]$} \\
Number of observations & 504 & & 164 & & & \\
\hline
\end{tabular}

*Significant at 10\%; **Significant at 5\%; **Significant at 1\%; Standard errors are in parentheses, and t-statistics are in brackets. Sample is households with children age 10-14 in which at least one adult has applied to Jefas. Data from Oct. $2001 \mathrm{EPH}$. All estimates are weighted by household size. Bolded text is used to signify impact estimates for primary outcomes.

2002, the Ministry of Labor estimated that $7.1 \%$ of children ages 5 to 14 were working (including in rural areas) and the ILO estimated that $2.2 \%$ of children ages $10-14$ in urban areas were working (World Bank, 2003). In contrast, the incidence of child work reported in Table 1 is $1.1 \%$. There is no evidence to suggest that under-reporting would have affected the treatment and comparison groups differentially, although this is impossible to verify ${ }^{6}$.

Table 2 shows post-program descriptive statistics for the 2,307 children in 1,535 households in the 2002 cross-section. Again, estimates are presented for demographic characteristics as well as the outcomes of interest, and separately by application status.

The unadjusted means in Table 2 suggest that the program may have had an impact on children's work and schooling: in 2002, the children of participants were less than half as likely to work as the children of applicants, and somewhat more likely to attend school. The unadjusted difference in means is statistically significant for work $(\mathrm{p}=0.047)$ but not for school attendance $(\mathrm{p}=0.101)$. If participants and applicants had been randomly assigned, the cross-sectional difference in means would serve as an unbiased estimate of program impacts: a 1.1 percentage point decline in child labor and a 1.5 percentage point increase in school attendance.

However, Table 2 also shows some evidence of imbalance between the treatment and comparison groups on household characteristics that are presumably immutable, such as the gender of the applicant. Although the evidence for pre-existing differences is slight, these imbalances suggest that the naïve impact estimate suggested by Table 2 should be viewed with caution.

Finally, Table 3 shows how selected observable characteristics changed between 2001 and 2002 for the panel sample of 984 children, again separately by application status of the parent. 
Table 2 Post-program descriptive statistics

\begin{tabular}{|c|c|c|c|c|c|c|}
\hline & \multicolumn{2}{|c|}{ Participants } & \multicolumn{2}{|c|}{ Applicants } & \multicolumn{2}{|c|}{$\begin{array}{c}\text { Difference } \\
\text { (part. - appl.) }\end{array}$} \\
\hline & Mean & St.err. & Mean & St.err. & Value & T-stat \\
\hline \multicolumn{7}{|l|}{ Outcomes of interest } \\
\hline Child works & 0.009 & $(0.002)$ & 0.020 & $(0.006)$ & -0.011 & {$[1.99]^{* *}$} \\
\hline Child attends school & 0.967 & $(0.004)$ & 0.952 & $(0.009)$ & 0.015 & [1.64] \\
\hline \multicolumn{7}{|l|}{ Attributes of children } \\
\hline Male & 0.511 & $(0.012)$ & 0.517 & $(0.021)$ & -0.007 & {$[0.29]$} \\
\hline Age & 11.889 & $(0.031)$ & 11.935 & $(0.053)$ & -0.046 & {$[0.76]$} \\
\hline \multicolumn{7}{|l|}{ Attributes of applicants } \\
\hline Applicant age & 37.07 & $(0.237)$ & 36.72 & $(0.479)$ & 0.352 & {$[0.73]$} \\
\hline Applicant is male & 0.315 & $(0.014)$ & 0.393 & $(0.024)$ & -0.077 & {$[2.82]^{* * *}$} \\
\hline Applicant is household head & 0.481 & $(0.015)$ & 0.466 & $(0.025)$ & 0.015 & {$[0.53]$} \\
\hline \multicolumn{7}{|l|}{ Attributes of the household } \\
\hline Lives in a shantytown & 0.059 & $(0.007)$ & 0.065 & $(0.014)$ & -0.006 & {$[0.45]$} \\
\hline Bathroom & 0.902 & $(0.009)$ & 0.874 & $(0.017)$ & 0.029 & {$[1.60]$} \\
\hline Rooms per person & 0.435 & $(0.007)$ & 0.457 & $(0.012)$ & -0.022 & {$[1.58]$} \\
\hline Number of children $<18$ in hhld & 4.104 & $(0.067)$ & 3.897 & $(0.102)$ & 0.207 & {$[1.62]$} \\
\hline Number of applicants in household & 1.202 & $(0.016)$ & 1.160 & $(0.020)$ & 0.042 & {$[1.44]$} \\
\hline Single household head & 0.083 & $(0.008)$ & 0.083 & $(0.014)$ & 0.000 & {$[0.00]$} \\
\hline Married household head & 0.448 & $(0.015)$ & 0.488 & $(0.025)$ & -0.040 & {$[1.37]$} \\
\hline Household size & 6.885 & $(0.087)$ & 6.542 & $(0.120)$ & 0.342 & {$[2.10]^{* *}$} \\
\hline Number of observations & 1,136 & & 399 & & & \\
\hline
\end{tabular}

*Significant at 10\%; **Significant at 5\%; **Significant at 1\%; Standard errors are in parentheses, and t-statistics are in brackets. Sample is households with children age 10-14 in which at least one adult has applied to Jefas. Data from Oct. 2002 EPH. All estimates are weighted by household size. Bolded text is used to signify impact estimates for primary outcomes.

The descriptive statistics in Table 3 support the narrative that households responded to the economic crisis by sending children into the workforce and that Jefas mitigated this behavior. Table 3 shows that the overall percentage of applicants' children who reported working tripled from $0.8 \%$ in 2001 (before the crisis) to $2.5 \%$ in 2002 (after the crisis) but remained unchanged for the children of participants during that same time. Likewise, school attendance fell for all children after the crisis but the change was more than twice as large among the children of applicants. Unconditional difference-indifferences estimates of Jefas' impact on work and school attendance are reported in Table 3 as 1.7 percentage points and 2.2 percentage points, respectively. The estimated impact on work is statistically significant while the impact on school attendance is not. Again, this is promising suggestive evidence that Jefas was effective at softening the effect of the crisis on vulnerable children. However, a more robust empirical strategy is necessary to allay concerns that these results may be influenced by selection bias.

\section{Empirical methodology}

For this analysis, I extend the methodological approach used by Galasso and Ravallion (2004) to study the program's impact on adult participants. Their strategy was to compare program participants with a propensity-matched group of program applicants who 
Table 3 Change from 2001-2002 for panel sample

\begin{tabular}{|c|c|c|c|c|c|c|c|c|c|c|}
\hline & \multicolumn{4}{|c|}{ Participants } & \multicolumn{4}{|c|}{ Applicants } & \multirow{2}{*}{\multicolumn{2}{|c|}{$\begin{array}{c}\text { Difference } \\
\text { (part. - appl.) }\end{array}$}} \\
\hline & \multirow{2}{*}{$\begin{array}{l}2001 \\
\text { Mean }\end{array}$} & \multicolumn{2}{|c|}{2002} & \multirow[b]{2}{*}{ T-stat } & \multirow{2}{*}{$\begin{array}{l}2001 \\
\text { Mean }\end{array}$} & \multicolumn{2}{|c|}{2002} & \multirow[b]{2}{*}{ T-stat } & & \\
\hline & & Mean & Change & & & Mean & Change & & Change & T-stat \\
\hline \multicolumn{11}{|l|}{ Outcomes of interest (2001) } \\
\hline Works & 0.011 & 0.011 & 0 & 0 & 0.008 & 0.025 & 0.017 & 1.67 & -0.017 & $1.96^{* *}$ \\
\hline Attends school & 0.985 & 0.969 & -0.016 & 2.32 & 0.983 & 0.945 & -0.037 & 2.95 & 0.022 & 1.51 \\
\hline \multicolumn{11}{|l|}{ Attributes of children (2001) } \\
\hline Male & 0.514 & 0.514 & 0 & 0 & 0.500 & 0.500 & 0 & 0 & 0.000 & 0.00 \\
\hline Age & 10.86 & 11.89 & 1.03 & 2.54 & 10.90 & 11.92 & 1.02 & 0.75 & 0.010 & 0.40 \\
\hline \multicolumn{11}{|l|}{ Attributes of the household (2001) } \\
\hline Lives in a shantytown & 0.051 & 0.052 & 0.001 & 0.16 & 0.063 & 0.054 & -0.008 & 0.68 & 0.009 & 0.61 \\
\hline Bathroom & 0.885 & 0.898 & 0.013 & 0.93 & 0.908 & 0.862 & -0.046 & 1.76 & 0.059 & $2.02^{* *}$ \\
\hline Rooms per person & 0.435 & 0.432 & -0.003 & 0.41 & 0.501 & 0.479 & -0.022 & 1.48 & 0.018 & 1.06 \\
\hline Number of children $<18$ in hhld & 4.212 & 4.205 & -0.007 & 0.19 & 3.996 & 3.866 & -0.130 & 2.14 & 0.123 & $1.74^{*}$ \\
\hline Single household head & 0.082 & 0.090 & 0.008 & 1.23 & 0.079 & 0.075 & -0.004 & 0.37 & 0.012 & 0.39 \\
\hline Married household head & 0.447 & 0.434 & -0.013 & 1.84 & 0.487 & 0.474 & -0.013 & 1.44 & -0.001 & 0.06 \\
\hline Household size & 7.093 & 7.132 & 0.039 & 0.81 & 6.766 & 6.707 & -0.059 & 0.69 & 0.098 & 1.00 \\
\hline Number of observations & 504 & 504 & & & 164 & 164 & & & & \\
\hline
\end{tabular}

*Significant at $10 \%$; * Significant at $5 \%$; ** Significant at $1 \%$. Note: test of age is a test of whether age increases by 1 year. Sample is households with children age $10-14$ in which at least one adult who has applied to Jefas. Data from Oct. 2002 and Oct. 2002 EPH. All estimates are weighted by household size. Bolded text is used to signify impact estimates for primary outcomes. 
had not yet received benefits. I employ the same basic approach to examine the effect of Jefas on children's work and school attendance in households with children ages 10-14.

In this paper, I construct a counterfactual outcome for each participant household using propensity scores. I estimate propensity scores at the household level to mirror the realworld household-level selection process. Propensity scores are estimated parametrically by fitting a probit model of participation (i.e., enrollment in Jefas) conditional on observed child- and household-level characteristics. I selected covariates for the propensity-score model based on their proximity to the program enrollment process; either because of their association with poverty and need (which may have caused households to apply early in the cycle) or because the attribute may be directly associated with preferential treatment in admission decisions (e.g., male applicants may have received preference). I then use the fitted model to predict a propensity score for each household.

Estimating program effects in this manner, outlined by Rosenbaum and Rubin (1983), is appealing in cases where (1) assignment to the treatment group can be made plausibly random conditional on observed covariates, and (2) there is sufficient overlap in the conditional probabilities of treatment between the treatment and comparison groups. I will argue that both conditions are met in this analysis.

Both the cross-sectional and panel samples are used for analysis, with propensity scores estimated separately for each sample. For the panel sample, I construct propensity scores using baseline covariates measured in 2001. For the much larger crosssectional sample, I use covariates measured in 2002 because baseline covariates are missing for approximately half of the observations.

Using covariates measured at follow-up to construct propensity scores must be done carefully to avoid matching on endogenous characteristics. The tradeoff is that the much larger sample size allows for more precise impact estimates. For the crosssectional sample, I estimate the propensity score using a combination of immutable characteristics (e.g. children's gender) and characteristics that do not appear to change between 2001 and 2002 based on analysis of changes in the longitudinal sample shown in Table 3. I rule out as candidates any characteristic that may have been affected by Jefas participation, based on either theoretical reasoning or empirical evidence. For example, an examination of the empirical evidence in Table 3 shows that the number of children in the household may have been affected by the Jefas program itself, as the number of children per household decreased by less than half as much among participants as among applicants from 2001 to 2002. Therefore, I rule out this characteristic as a candidate for calculating the propensity score.

The final list of characteristics used for estimating the propensity score is shown in Table 4, along with coefficients from the fitted model for the cross-sectional sample. Coefficient estimates in the panel sample are similar in magnitude. Although several covariates are significant in this regression, the model has low explanatory power $\left(R^{2}=0.04\right)$, which is consistent with the clear ex ante similarity of observable characteristics between applicant and participant households.

Given the arguably arbitrary nature of program enrollment, it is also not surprising that there is a large region of overlapping support, shown graphically in Figure 1 for the cross-sectional sample. Of the 1,535 total observations in the cross-sectional sample, 6 observations (all in the treatment group) fall outside the region of common support. Of 668 observations in the panel sample, 23 observations are off support. 
Table 4 Probit regression for calculating the propensity score in the cross-sectional sample

\begin{tabular}{|c|c|}
\hline & Program participation \\
\hline \multirow[t]{2}{*}{ Male child } & -0.04 \\
\hline & $(0.09)$ \\
\hline \multirow[t]{2}{*}{ Children's age } & -0.05 \\
\hline & $(0.03)$ \\
\hline \multirow[t]{2}{*}{ Applicant's age } & 0.01 \\
\hline & $(0.01)$ \\
\hline \multirow[t]{2}{*}{ Applicant is female } & $-0.38^{* * *}$ \\
\hline & $(0.11)$ \\
\hline \multirow[t]{2}{*}{ Applicant is household head } & $0.19^{* *}$ \\
\hline & $(0.10)$ \\
\hline \multirow[t]{2}{*}{ Number of applicants in household } & $0.20^{* *}$ \\
\hline & $(0.08)$ \\
\hline \multirow[t]{2}{*}{ Lives in a shantytown } & -0.07 \\
\hline & $(0.17)$ \\
\hline \multirow[t]{2}{*}{ Rooms per person } & -0.24 \\
\hline & $(0.16)$ \\
\hline \multirow[t]{2}{*}{ Household head is married } & -0.03 \\
\hline & $(0.09)$ \\
\hline \multirow[t]{2}{*}{ Household head is single } & -0.16 \\
\hline & $(0.14)$ \\
\hline \multirow[t]{2}{*}{ Region: cuyo } & $-0.73^{* * *}$ \\
\hline & $(0.13)$ \\
\hline \multirow[t]{2}{*}{ Region: noroeste } & $-0.19^{* *}$ \\
\hline & $(0.10)$ \\
\hline \multirow[t]{2}{*}{ Region: nordeste } & -0.12 \\
\hline & $(0.11)$ \\
\hline Number of observations & 2306 \\
\hline Number treated off support & 0 \\
\hline Pseudo R2 & 0.04 \\
\hline
\end{tabular}

*Significant at $10 \% ; *$ Significant at $5 \% ; * *$ Significant at $1 \%$. Standard errors are in parentheses. Notes: Sample is children age 10-14 who have a parent who applied to Jefas. Data from Oct. $2002 \mathrm{EPH}$.

Based on these findings, I conclude that propensity matching using either the 2002 cross-sectional sample or the panel sample meets the criteria outlined by Rosenbaum and Rubin (1983) and is an appropriate method of estimating the average treatment effect on the treated (ATT).

With propensity scores in hand, I estimate the counterfactual outcome for each treatment household in the following manner. First, I take weighted averages over outcomes for households in the applicant group, who are observationally similar to the participants in terms of their propensity scores. There are $N$ participants indexed $i=1, \ldots$, $N$ and $P$ applicants indexed $j=1, \ldots, P$. Let $Y_{i}^{K}$ be the outcome of interest for household $i$ in state $K$, where $K=T$ for participants (the treated group) and $K=C$ for applicants 


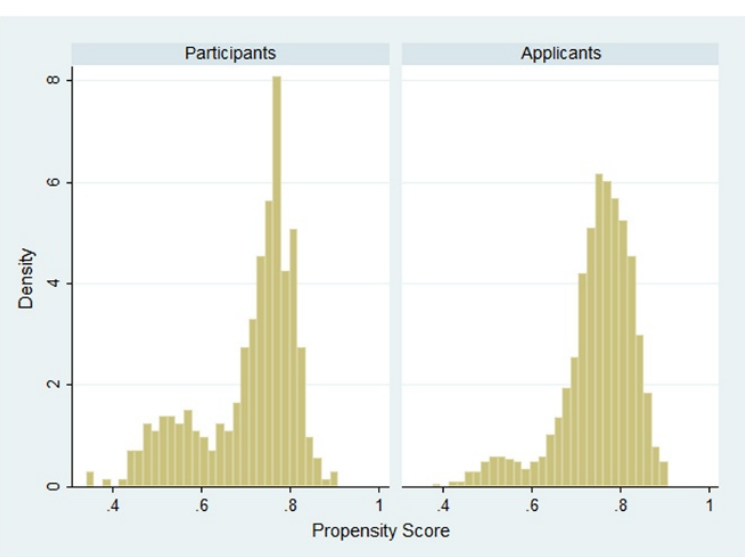

Figure 1 Overlapping support in the distribution of the propensity score.

(the comparison group). Applying weights $W_{i j}$ to calculate the counterfactual for each participant, the estimate of the mean impact is

$$
\frac{1}{N} \sum_{i=1}^{N}\left(Y_{i}^{T}-\sum_{j=1}^{P} W_{i j} Y_{j}^{C}\right)
$$

where for each $i$

$$
\sum_{j=1}^{P} W_{i j}=1
$$

Following Galasso and Ravallion (2004), I use local linear weights, which are constructed using all individuals in the control group and which have been found to perform well at the boundaries of the propensity score. Local linear weighting is competitive with other estimators in terms of bias so long as there is good common support (which is the case here), and achieves lower variance than many estimators because more information is used (Busso et al. 2009). Matching is implemented in Stata using $<$ psmatch $2>$ with a default bandwidth of 0.8 (Leuven and Sianesi 2003).

Impact estimates are calculated using the cross-sectional sample as the difference between the average treatment group outcome and the average propensity-matched comparison group outcome, weighting household-level observations by number of children. Analysis in the panel sample proceeds in the same manner, except using a differencein-differences approach in which the change from 2001-2002 is first calculated for each group. Impact estimates are then calculated as the difference between the change in the treatment group and the change in the propensity-matched comparison group. Standard errors are bootstrapped with 100 repetitions $^{7}$.

\section{Main findings}

Before proceeding to estimate the impact of Jefas on child work and school attendance, I use the methodology described in Section 5 to replicate the impacts presented in Galasso and Ravallion (2004), Table Eight, p. 388. This exercise serves two purposes. First, it provides reassurance that I have correctly implemented the methodology outlined above. Second, it demonstrates the degree to which impacts on adult outcomes 
differ between the full sample of participants examined in Galasso and Ravallion (2004) and the smaller sample of participants with children between the ages of 10 and 14 that is the focus of this paper.

Table 5 presents conditional means, matched cross-sectional estimates, and matched difference-in-differences estimates for each sample. The first row for each sample in Table 5 shows the estimates from Table Eight in Galasso and Ravallion (2004). The second row replicates those estimates using the full sample of participant and applicant households constructed for this paper. The third row shows estimates for the sample of households with children ages 10-14.

In the full sample of 3,509 participant and applicant households, I find point estimates and standard errors that are uniformly within $10 \%$ of (and frequently equivalent to) the original magnitudes reported in Galasso and Ravallion (2004).

Among the smaller sample of 1,529 households with children ages 10-14, point estimates are remarkably similar to those for the full sample. The most noticeable difference in impacts between the two samples is for household income. Although the impact on individual income is similar across the two samples, the impact on total household income is substantially smaller in the subset of households with children ages 10-14. I will revisit this finding and suggest a potential interpretation after presenting the main impact estimates.

Table 5 Replication of Galasso and Ravallion (2004) Table Eight: treatment group means and impacts

\begin{tabular}{|c|c|c|c|c|c|c|}
\hline & $\begin{array}{l}\text { Household } \\
\text { income }\end{array}$ & $\begin{array}{l}\text { Individual } \\
\text { income }\end{array}$ & $\begin{array}{c}\text { Individual } \\
\text { employment }\end{array}$ & $\begin{array}{c}\text { Individual } \\
\text { unemployment }\end{array}$ & $\begin{array}{l}\text { Individual } \\
\text { inactivity }\end{array}$ & $\begin{array}{c}\text { Total hours } \\
\text { worked/week }\end{array}$ \\
\hline \multicolumn{7}{|l|}{$\begin{array}{l}\text { Treatment group } \\
\text { mean }\end{array}$} \\
\hline $\begin{array}{l}\text { Galasso and } \\
\text { Ravallion (2004) }\end{array}$ & 438.3 & 172.9 & 0.86 & 0.04 & 0.10 & 20.6 \\
\hline $\begin{array}{l}\text { Replication using } \\
\text { full sample }\end{array}$ & 419.8 & 169.5 & 0.85 & 0.05 & 0.10 & 20.3 \\
\hline $\begin{array}{l}\text { Households with } \\
\text { children age 10-14 }\end{array}$ & 398.1 & 168.5 & 0.85 & 0.05 & 0.10 & 20.3 \\
\hline \multicolumn{7}{|l|}{$\begin{array}{l}\text { Matched single } \\
\text { difference }\end{array}$} \\
\hline $\begin{array}{l}\text { Galasso and } \\
\text { Ravallion (2004) }\end{array}$ & $81.19(16.0)$ & $89.2(5.27)$ & $0.49(0.02)$ & $-0.26(0.02)$ & $-0.23(0.02)$ & $9.2(0.8)$ \\
\hline $\begin{array}{l}\text { Replication using } \\
\text { full sample }\end{array}$ & $79.88(17.1)$ & $91.4(6.00)$ & $0.49(0.02)$ & $-0.25(0.02)$ & $-0.23(0.02)$ & $9.2(0.6)$ \\
\hline $\begin{array}{l}\text { Households with } \\
\text { children age 10-14 }\end{array}$ & $69.5(6.9)$ & $92.1(6.91)$ & $0.49(0.03)$ & $-0.21(0.02)$ & $-0.27(0.03)$ & $10.0(0.9)$ \\
\hline \multicolumn{7}{|l|}{$\begin{array}{l}\text { Matched difference- } \\
\text { in-differences }\end{array}$} \\
\hline $\begin{array}{l}\text { Galasso and } \\
\text { Ravallion (2004) }\end{array}$ & $103.41(32.3)$ & $113.6(15.1)$ & $0.46(0.04)$ & $-0.23(0.04)$ & $-0.23(0.04)$ & $8.9(1.5)$ \\
\hline $\begin{array}{l}\text { Replication using } \\
\text { full sample }\end{array}$ & 92.33 (28.8) & $95.67(10.7)$ & $0.42(0.04)$ & $-0.22(0.04)$ & $-0.20(0.04)$ & $8.9(2.0)$ \\
\hline $\begin{array}{l}\text { Households with } \\
\text { children age 10-14 }\end{array}$ & $67.08(41.1)$ & $101.1(21.9)$ & $0.41(0.07)$ & $-0.25(0.06)$ & $-0.16(0.06)$ & $7.3(3.1)$ \\
\hline
\end{tabular}

Notes: Standard errors in parentheses, bootstrapped with 100 repetitions. Sample sizes are 3,509 for the full sample and 1,529 for the sample of households with children ages 10-14. Source: Galasso and Ravallion (2004) and author's calculations from EPH. Incomes are reported in 2002 dollars. 
Propensity-matched estimates of the average impact on children's work and school attendance using the 2002 cross-section are shown in Table 6. Propensity-matched differences in the explanatory covariates are shown below the main impact estimates to demonstrate that propensity matching was successful at providing balance.

The estimates in Table 6 indicate that a household's participation in Jefas leads to a 0.6 percentage point decrease in the probability that a child works, from $1.3 \%$ to $0.7 \%$. Likewise, participation causes an increase in the probability of school attendance of 2.0 percentage points, from $94.8 \%$ to $96.8 \%^{8}$. The estimate for school attendance is significant at a $90 \%$ confidence level, while the estimate for work is not significant ${ }^{9}$. There are no significant differences in weighted means between the treatment and comparison groups on any other demographic characteristics or household attributes after adjusting for the propensity score.

As noted earlier, one possible source of concern regarding the cross-sectional estimates of program impact is that the observable household characteristics used to calculate the propensity score were measured after the program had been implemented. As a result, some or all of those characteristics may have been affected by program participation. To address this concern, Table 7 presents propensity-matched difference-indifferences estimates for the panel sample. In this sample, propensity scores were estimated using only pre-intervention baseline (2001) data. Table 7 shows the pre-topost intervention change in outcomes for the treatment group, the pre-to-post intervention change in outcomes for the comparison group, and the difference between the two groups. Because the panel sample is only $45 \%$ as large as the cross-sectional sample, standard errors are larger in this analysis.

The impact estimates for work and school attendance in Table 7 are both within 0.2 percentage points of the estimates in Table 5. The propensity-matched difference-in differences estimates shown in Table 7 indicate a 0.8 percentage point impact on

Table 6 Propensity-matched estimate of the average impact of participation on work and school attendance

\begin{tabular}{|c|c|c|c|c|}
\hline & \multirow[t]{2}{*}{ Participants } & \multirow{2}{*}{$\begin{array}{l}\text { Weighted } \\
\text { controls }\end{array}$} & \multirow{2}{*}{\multicolumn{2}{|c|}{$\begin{array}{c}\text { Difference } \\
\text { (Treatment - Control) }\end{array}$}} \\
\hline & & & & \\
\hline & Mean & Mean & Diff & t-stat \\
\hline Works & 0.007 & 0.013 & -0.006 & 1.11 \\
\hline Attends school & 0.968 & 0.948 & 0.020 & $1.76^{* *}$ \\
\hline Male child & 0.511 & 0.521 & -0.012 & 0.40 \\
\hline Child's age & 11.892 & 11.854 & 0.015 & 0.35 \\
\hline Applicant's age & 37.111 & 37.833 & -0.722 & 0.82 \\
\hline Applicant is female & 0.316 & 0.306 & 0.010 & 0.05 \\
\hline Applicant is household head & 0.478 & 0.500 & -0.022 & 0.68 \\
\hline Number of applicants in household & 1.189 & 1.190 & -0.001 & 0.22 \\
\hline Lives in a shantytown & 0.059 & 0.061 & -0.002 & 0.30 \\
\hline Rooms per person & 0.437 & 0.458 & -0.021 & 0.46 \\
\hline Household head is married & 0.449 & 0.448 & 0.002 & 0.92 \\
\hline Household head is single & 0.083 & 0.103 & -0.008 & 0.39 \\
\hline Number of observations & 1,130 & 399 & & \\
\hline
\end{tabular}

*Significant at 10\%; **Significant at 5\%; ***Significant at $1 \%$. Notes: Sample is households with children age 10-14, in which at least one adult has applied to Jefas. Data from Oct. $2002 \mathrm{EPH}$. Estimates are weighted by household size. 
Table 7 Propensity-matched difference-in-differences estimate of the average impact of participation on work and school attendance using the longitudinal sample

\begin{tabular}{|c|c|c|c|c|}
\hline & \multirow{3}{*}{$\begin{array}{l}\text { Participants } \\
2001-2002 \\
\text { Change }\end{array}$} & \multirow{3}{*}{$\begin{array}{c}\text { Weighted } \\
\text { controls } \\
\text { 2001-2002 } \\
\text { Change }\end{array}$} & \multirow{2}{*}{\multicolumn{2}{|c|}{$\begin{array}{c}\text { Difference } \\
\text { (Participants - Controls) }\end{array}$}} \\
\hline & & & & \\
\hline & & & $\begin{array}{c}\text { D-D } \\
\text { Estimate }\end{array}$ & T-stat \\
\hline Works & 0.001 & 0.009 & -0.008 & 1.16 \\
\hline Attends school & -0.017 & -0.035 & 0.018 & 0.91 \\
\hline Male child & 0.000 & 0.000 & 0.000 & 0.00 \\
\hline Child's age & 1.024 & 1.048 & -0.024 & 0.50 \\
\hline Lives in a shantytown & -0.003 & 0.003 & -0.006 & 0.30 \\
\hline Bathroom & 0.008 & -0.035 & 0.043 & 1.59 \\
\hline Rooms per person & 0.435 & 0.439 & -0.004 & -0.23 \\
\hline Number of children $<18$ in hhld & 4.212 & 4.042 & 0.170 & 0.91 \\
\hline Household head is single & 0.074 & 0.070 & 0.004 & 0.25 \\
\hline Household head is married & 0.471 & 0.484 & -0.013 & -0.29 \\
\hline Household size & 7.093 & 6.820 & 0.273 & 1.12 \\
\hline Number of observations & 481 & 164 & & \\
\hline
\end{tabular}

Notes: Sample is households with children age 10-14, in which at least one parent has applied to Jefas. Data from EPH. Estimates are weighted by household size. Bolded text is used to signify impact estimates for primary outcomes.

working and a 1.8 percentage point impact on school attendance. The program's estimated effect on work is no longer statistically significant in this smaller sample. Once again, conditional on weighting there is no evidence of substantively or statistically significant imbalance in demographic characteristics between the treatment and comparison groups.

Recall from Table 5 that participants with children ages 10-14 experience a smaller gain in household income than other participants, even though the impact on the participant's own income is equally large. The results in Tables 6 and 7 seem consistent with this finding, for two reasons. First, cessation of child work for pay will mechanically decrease the net impact of Jefas income on total household income. This effect would not be observed in households with only very young children or children old enough to have committed to the workforce. Second, the estimated increase in a child's school attendance might come at the expense of domestic production (e.g. caring for younger children). Because Jefas work hours are inflexible, other adult members of the household who have more flexibility might curtail their work effort outside the home so as to compensate for the affected child's reduced domestic production. This effect also would not be observed in households with children who already attend school regularly (i.e. children younger than 10) or children do not attend at all (e.g. children older than 14 who have committed to the workforce). Both mechanisms imply that the impact should be smaller in households that have children ages 10-14 than for other households, which we observe to be the case.

Finally, to put the results in Tables 6 and 7 in context, note that there were around 2 million Jefas participants in October 2002. Each participant had on average 0.9 children between ages 10-14, for a total of about 1,792,800 children in this age group. Taken at face value, the average point estimates in Tables 6 and 7 suggest that as a result of the program 12,550 fewer children worked and 34,063 more children attended school than 
would have been the case without Jefas. With program funding of around 1\% of GDP, or $\$ 333$ million, the cost of averting work is approximately $\$ 30,956$ per child and the cost per additional child in school is approximately $\$ 9,287$. Given that the base rate of child work is likely to be underreported in the $\mathrm{EPH}$, these figures are likely to understate the number of affected children and overstate the pecuniary cost of averting work for pay.

\section{Additional analyses}

This section presents estimates from parametric and doubly-robust impact estimators. The parametric estimates provide evidence on variation in the impact by subgroup, as well as confirm the earlier results under a different set of assumptions. Doubly-robust estimates provide additional reassurance that the earlier results are not sensitive to the estimation strategy.

To determine whether the impact varies by characteristics such as by age or gender, I turn to a parametric specification. Whereas the semiparametric techniques employed in the previous section require that assignment into the treatment group be random conditional on observable characteristics, traditional parametric estimation of treatment effects requires assumptions about the full relationship between the observed characteristics and outcomes of interest. If such assumptions can be reasonably made, then parametric regression models with treatment"covariate interactions can yield additional insight into treatment effect heterogeneity; i.e. "what works best for whom."

I examine variation using a simple linear model. The model includes interactions between the treatment and explanatory characteristics that could affect the treatment, in particular the age of the child, the gender of the child, and the gender of the parent who applied to Jefas. I construct an estimate of the overall ATT for comparison with earlier estimates using predictions from the fitted model. First, I predict the probability of the outcome variable for each treated observation with the treatment set to 1 . Next, I predict the outcome with the treatment dummy set to zero. The difference is the estimate of ATT. To illustrate, let $x_{i 1} \ldots x_{i K}$ be a vector of covariates and interaction terms, and let $T$ represent a dummy variable equal to 1 for program participants. After fitting the model to estimate $\hat{\beta}_{0} \ldots \hat{\beta}_{K}, \hat{\beta}_{T}$ on the whole sample, ATT would be estimated using only the sample of participants as

$$
\frac{1}{N} \sum_{i=1}^{N}\left[\left(\hat{\beta}_{0}+\hat{\beta}_{1} x_{i 1}+\ldots+\hat{\beta}_{K} x_{i K}+\hat{\beta}_{T}\right)-\left(\hat{\beta}_{0}+\hat{\beta}_{1} x_{i 1}+\ldots+\hat{\beta}_{K} x_{i K}\right)\right]
$$

Coefficients and standard errors from a linear regression including interactions of treatment with child's gender, child's age, and the gender of the parent who applied to the Jefas program are shown in Table 8 for each of the two outcomes ${ }^{10}$.

The treatment and treatment"interaction coefficients are not jointly significant at $\mathrm{p}<0.10$ in either of these regressions. Using the fitted linear model to calculate ATT, participation in Jefas is estimated to cause a 1.2 percentage point reduction in the probability that a child reports working and a 1.7 percentage point reduction in the likelihood of skipping school. The estimated impact on school attendance is similar in magnitude to the estimates in Tables 6 and 7, while the estimated impact on child work is larger. 
Table 8 Linear regressions for work and school attendance

\begin{tabular}{|c|c|c|}
\hline & Works & Attends school \\
\hline \multirow[t]{2}{*}{ Jefas participant } & -0.001 & 0.129 \\
\hline & $(0.056)$ & $(0.079)$ \\
\hline \multirow[t]{2}{*}{ Treatment*male applicant } & $0.022^{*}$ & 0.005 \\
\hline & $(0.013)$ & $(0.021)$ \\
\hline \multirow[t]{2}{*}{ Treatment*female child } & 0.017 & -0.032 \\
\hline & $(0.015)$ & $(0.020)$ \\
\hline \multirow[t]{2}{*}{ Treatment ${ }^{*}$ child age } & 0.002 & -0.008 \\
\hline & $(0.006)$ & $(0.007)$ \\
\hline \multirow[t]{2}{*}{ Child is female } & $-0.023^{*}$ & $0.047^{* *}$ \\
\hline & $(0.014)$ & $(0.018)$ \\
\hline \multirow[t]{2}{*}{ Child's age } & $0.009^{*}$ & $-0.015^{* *}$ \\
\hline & $(0.005)$ & $(0.006)$ \\
\hline \multirow[t]{2}{*}{ Applicant's age } & 0.000 & -0.001 \\
\hline & $(0.000)$ & $(0.001)$ \\
\hline \multirow[t]{2}{*}{ Applicant is male } & $-0.030^{* *}$ & 0.004 \\
\hline & $(0.015)$ & $(0.020)$ \\
\hline \multirow[t]{2}{*}{ Applicant is household head } & $0.011^{*}$ & -0.005 \\
\hline & $(0.008)$ & $(0.011)$ \\
\hline \multirow[t]{2}{*}{ Number of applicants in household } & $0.021^{* *}$ & -0.001 \\
\hline & $(0.019)$ & $(0.010)$ \\
\hline \multirow[t]{2}{*}{ Lives in a shantytown } & 0.006 & -0.007 \\
\hline & $(0.012)$ & $(0.019)$ \\
\hline \multirow[t]{2}{*}{ Rooms per person } & $-0.027^{* *}$ & $0.080^{* * *}$ \\
\hline & $(0.010)$ & $(0.020)$ \\
\hline \multirow[t]{2}{*}{ Household head is married } & -0.006 & $0.022^{* *}$ \\
\hline & $(0.006)$ & $(0.010)$ \\
\hline \multirow[t]{2}{*}{ Household head is single } & $-0.015^{*}$ & 0.004 \\
\hline & $(0.008)$ & $(0.016)$ \\
\hline \multirow[t]{2}{*}{ Constant } & $-0.085^{*}$ & $1.093^{* * *}$ \\
\hline & $(0.050)$ & $(0.065)$ \\
\hline R2 & 0.04 & 0.04 \\
\hline Number of observations & 1535 & 1535 \\
\hline
\end{tabular}

*Significant at $10 \%$; * Significant at $5 \%$; **Significant at $1 \%$. Standard errors are in brackets, and are robust to clustering at the household level. Note: Sample is children age 10-14, who have a parent who has applied to Jefas. Data from Oct. 2002 EPH. Both regressions include region dummies. Bolded text is used to signify impact estimates for primary outcomes.

The estimated impact of Jefas on child work varies significantly by gender of the applicant-so much so that the average treatment effect is driven entirely by the children of female applicants. None of the other interaction terms are significant in this regression, but the sign on the coefficients suggests that male children benefit more from the program than female children and that younger children benefit more than older children; the latter is what would be expected if there is more of a social stigma to sending younger children into the labor force.

None of the interaction terms are significant in the regression for school attendance. However, the signs again suggest that younger children benefit more from the program 
than older children, as would be expected if families value education more for younger children than for children who are approaching working age. The school-attendance regression also suggests that the impact of participation on schooling is larger for male children and possibly for the children of male applicants.

Finally, I calculate doubly-robust estimates of the program's impact on work and school attendance. This exercise serves as an additional test of the robustness of the parametric and non-parametric results. Doubly-robust estimation combines propensityscore weighting with regression modeling of the relationship between covariates and the outcome for the treatment and control groups separately (Imbens and Wooldridge 2009). These estimates will be unbiased if either the propensity-score model or the outcome regression model is correctly specified. If both are correctly specified, the doublyrobust estimates will also have smaller variances than the semiparametric estimates.

To calculate doubly-robust estimates, I follow the procedure outlined on page 339 of Emsley et al. (2008). Standard errors are bootstrapped with 100 replications. There is no currently-accepted method of incorporating sampling weights into the doublyrobust estimation procedure. Therefore, to produce child-level estimates that are comparable with those above, I use a child-level dataset produced by disaggregating the cross-sectional household-level dataset. The disaggregated dataset includes a sample of 2,306 child-level observations (clustered in 1,529 households).

Doubly-robust estimates are presented in Table 9 for each of the two outcomes.

The doubly-robust estimates are similar to the main semiparametric estimates reported in Tables 6 and 7 and the parametric estimates calculated from Table 8. The estimated impact on child work of 1.0 percentage points is slightly larger than the semiparametric estimates. The estimated 1.8 percentage-point impact on school attendance is equivalent to the difference-in-difference estimate. The similarity of impact estimates produced by semiparametric, parametric, and doubly-robust estimation strategies lends confidence to the main results.

Table 9 Doubly-robust child-level estimates

\begin{tabular}{lcc}
\hline & Impact estimate & T-stat \\
\hline Works & $-\mathbf{0 . 0 1 0}$ & $1.88^{*}$ \\
Attends school & $\mathbf{0 . 0 1 8}$ & $1.73^{*}$ \\
Male child & -0.009 & 0.37 \\
Child's age & -0.011 & 0.15 \\
Applicant's age & -0.009 & 0.02 \\
Applicant is male & -0.005 & 0.29 \\
Applicant is household head & 0.001 & 0.05 \\
Number of applicants in household & 0.000 & 0.01 \\
Lives in a shantytown & -0.004 & 0.31 \\
Rooms per person & 0.001 & 0.06 \\
Household head is married & -0.012 & 0.55 \\
Household head is single & -0.004 & 0.33 \\
Number of observations & &
\end{tabular}

*Significant at $10 \%$; ${ }^{*}$ Significant at $5 \%$; ${ }^{* *}$ Significant at $1 \%$.

Notes: Sample is children age 10-14; data from $2002 \mathrm{EPH}$. Estimates for independent variables are calculated using a doubly-robust model in which the variable of interest is used to calculate the propensity score only. Bolded text is used to signify impact estimates for primary outcomes. 


\section{Conclusion}

This study presents evidence that parents' participation in the Jefas public employment program helped alleviate child labor and increase school attendance for children age 10-14 in Argentina. Impact estimates are found by comparing participants with a propensity-matched group of program applicants not receiving benefits. Estimates using cross-sectional data from 2002 indicate that participation reduced the reported incidence of child work by $46 \%$ ( 0.6 percentage points), and decreased absenteeism by $38 \%$ (2.0 percentage points). Difference-indifferences estimates using the smaller panel sample confirm these results, suggesting program effects of 0.8 percentage points on child work and 1.8 percentage points on school attendance.

These results are consistent with the observation that participants who have children ages 10-14 experience a smaller gain in household income than other participants, even though the impact on the participant's own income is equally large. The smaller net gain for such households may be due in part to reduced income from child work. Adults may also adjust their labor supply to compensate for lost home production of children who are newly attending school.

Parametric estimates of ATT suggest that the children of female participants benefit significantly more from the program than the children of male participants. Although not statistically significant, these estimates also suggest that younger children benefit more from the program than older children in terms of school attendance. This would be expected if families value education more for younger children than for children who are approaching working age. Similarly, the parametric estimates suggest that boys benefit more from the program than girls and that younger children benefit more than older children; the latter is what would be expected if there is more of a social stigma to sending younger children into the labor force.

The similarity of estimates derived using parametric, semiparametric, and doublyrobust estimation techniques alleviates concerns about the validity of underlying assumptions. Results from the panel sample alleviate concerns that the cross-sectional impact estimates could be due to selection bias in the form of pre-existing differences between the treatment and control groups.

Back of the envelope calculations show that the Jefas program likely caused a reduction in the number of children working in Argentina of around 12,550 and an increase in the number attending school of around 34,063. These estimates are likely to understate the number of affected children due to underreporting of child labor in the EPH.

\section{Endnotes}

${ }^{1}$ The World Bank calculated the expected hourly wage rate (averaging formal and informal work) in the first income decile as AR $\$ 0.97$ and in the second decile as AR $\$ 2.01$. This corresponds to monthly incomes of AR $\$ 180$ and AR $\$ 370$, respectively.

${ }^{2}$ It is unclear exactly what applicants were told regarding their possibilities for future participation. The September cutoff was "unofficial" and appears not to have been strictly enforced. A small amount of additional enrollment occurred after September 2002, most notably right before the presidential elections.

${ }^{3}$ Note that The EPH has a strong commitment to anonymity, which means that participants could report adverse information-e.g. information that would disqualify them from the program-without fear of reprisal. 
${ }^{4}$ Madrian and Lefgren (2000) suggest verifying that race does not change from year to year; this is not feasible using EPH data, as race variables are not similar to those used in the CPS. Note that this process results in the exclusion of individual child-level observations. If gender and/or age do not match for any children in a household, the household is dropped from the sample entirely regardless of adult-level matches.

${ }^{5} \mathrm{~A}$ test of joint significance of all 11 variables finds significant evidence of imbalance $(\mathrm{p}=0.07)$; a test of the 10 variables excluding rooms per person finds no evidence of imbalance $(\mathrm{p}=0.73)$.

${ }^{6}$ The most likely reason for differential under-reporting to occur would be if, despite the survey's guarantee of anonymity, children of participants or their parents (they answered the survey together) were less likely to report child work for fear of being dropped from the program.

${ }^{7}$ Although Abadie and Imbens (2008) show that bootstrapping may be inappropriate for one-to-one matching, as far as I am aware there is no comparable evidence to suggest it would be inappropriate for weighting.

${ }^{8}$ Note that the propensity-matched estimate of child work in the treatment group of 0.6 percent differs from the estimate of 0.9 percent shown in Table 2. The estimates are different because a disproportionate number of treatment-group households that were dropped for lack of common support had children who were reported as working.

${ }^{9}$ As it turns out, the results are not particularly sensitive to the choice of weights. For example, using kernel rather than local linear weights produces point estimates of the impact of 1.0 percentage points for working, and 2.3 percentage points for school attendance, with a similar level of precision.

${ }^{10}$ These standard errors are robust to clustering at the household level. Accounting for clustering has little effect on the standard errors in the linear model.

\section{Competing interests}

The IZA Journal of Labor \& Development is committed to the IZA Guiding Principles of Research Integrity. The author declares that he has observed these principles.

\footnotetext{
Acknowledgements

I am grateful to Gary Solon, Stacy Dickert-Conlin, Stephen Woodbury, Jacob Klerman, Fatih Unlu, Soren Anderson, and three anonymous referees for detailed comments and feedback. I would also like to thank seminar participants at Michigan State University, Western Michigan University, the World Bank, and Abt Associates for their useful suggestions. Financial support was provided by a Dissertation Completion Fellowship from the Graduate School at Michigan State University and a Daniel McGillis Development and Dissemination Grant from Abt Associates Inc.
}

Responsible editor: Jackline Wahba

Received: 4 April 2014 Accepted: 23 June 2014

Published: 21 Aug 2014

References

Abadie A, Imbens GW (2008) On the failure of the bootstrap for matching estimators. Econometrica 76:1537-1557 Attanasio O, Fitzsimons E, Gomez A, Lopez D, Meghir C, Mesnard A (2006) Child education and work choices in the presence of a conditional cash transfer programme in rural Colombia (IFS Working Paper W06/01). Institute for Fiscal Studies, London

Basu K, Van PH (1998) The economics of child labor. Am Econ Rev 88:412-427

Besley T, Coate S (1992) Workfare versus welfare: Incentive arguments for work requirements in poverty-alleviation programs. Am Econ Rev 82:249-261

Bureau of International Affairs, U.S. Department of Labor (2009) The Department of Labor's 2008 Findings on the Worst Forms of Child Labor. Government Printing Office, Washington. http://www.dol.gov/ilab/reports/

Busso M, DiNardo J, McCrary J (2009) Finite sample properties of semiparametric estimators of average treatment effects. University of Michigan, Ann Arbor, MI. Working paper, Accessed July 2, 2014 at http://www-personal.umich. edu/ jdinardo/BDM2008_v11.pdf

Edmonds E, Schady N (2009) Poverty alleviation and child labor (NBER Working Paper 15345). Retrieved July 2, 2014 at http://www.nber.org/papers/w15345 
Emsley R, Lunt M, Pickles A, Dunn G (2008) Implementing Double-Robust Estimators of Causal Effects. Stata J 3:334-353 Fernandez F, Saldarriaga V (2014) Do benefit recipients change their labor supply after receiving the cash transfer? Evidence from the Peruvian Juntos program. IZA J Lab Development 3:2

Filmer D, Schady N (2008) Getting girls into school: Evidence from a scholarship program in Cambodia. Econ Dev Cult Change 56:581-617

Fiszbein A, Schady N (2009) Conditional Cash Transfers: Reducing Present and Future Poverty. World Bank, Washington, DC Galasso E, Ravallion M (2004) Social protection in a crisis: Argentina's Plan Jefes y Jefas. World Bank Econ Rev 18(3):367-399 Hennigan T (2003) Recession pulls children out of Argentina's classrooms. Christian Science Monitor (Buenos Aires), June 25. Accessed July 2, 2014 at http://www.csmonitor.com/2003/0625/p07s02-woam.html ILO-IPEC (2002) La OIT celebra el primer "Día mundial contra el trabajo infantil." Press release, Buenos Aires Imbens G, Wooldridge J (2009) Recent Developments in the Econometrics of Program Evaluation. J Econ Lit 47(1):5-86 INDEC (2001) Resultados nacionales [national census results]

Leuven E, Sianesi B (2003) PSMATCH2: Stata module to perform full Mahalanobis and propensity score matching, common support graphing, and covariate imbalance testing, Version 1.2.3. Accessed July 2, 2014 at http://ideas.repec.org/c/boc/bocode/s432001.html

Madrian BC, Lefgren $\sqcup$ (2000) An approach to longitudinally matching population survey (CPS) respondents. J Econ Soc Meas 26:31-62

McKenzie D (2004) Aggregate shocks and labor market responses: Evidence from Argentina's financial crisis. Econ Dev Cult Change 52:719-758

Palacios C (2003) Crece la población de chicos en las calles. La Nación (Buenos Aires), July, 29

Ravallion M (1990) Reaching The Poor Through Rural Public Employment; A Survey Of Theory And Evidence. World Bank - Discussion Papers 94, World Bank, Washington, DC. (http://documents.worldbank.org/curated/en/1990/07/ 440466/reaching-poor-through-rural-public-employment-survey-theory-evidence)

Rosenbaum P, Rubin D (1983) The central role of the propensity score in observational studies for causal effects. Biometrika 70:41-50

Schultz T (2004) School subsidies for the poor: Evaluating the Mexican Progresa poverty program. J Dev Econ 74:199-250 World Bank (2003) World development indicators 2003. CD-ROM, Washington, D.C.

World Bank (2006) Project appraisal document on a proposed loan in the amount of US\$350 million to the Argentine Republic for a heads of household transition project (Report No. 32463-AR). World Bank, Washington, DC. (http://siteresources.worldbank.org/INTARGENTINA/Resources/PAD.pdf)

10.1186/2193-9020-3-14

Cite this article as: Juras: The effect of public employment on children's work and school attendance: evidence from a social protection program in Argentina. IZA Journal of Labor \& Development 2014, 3:14

\section{Submit your manuscript to a SpringerOpen ${ }^{\circ}$ journal and benefit from:}

- Convenient online submission

- Rigorous peer review

- Immediate publication on acceptance

- Open access: articles freely available online

- High visibility within the field

- Retaining the copyright to your article

Submit your next manuscript at $\boldsymbol{\sim}$ springeropen.com 